\author{
伊藤隆一*1, 山崎光 悦*2, 韓晶*1
}

\title{
A Study on Openability of an Aluminum Beverage Bottle
}

\author{
Ryoichi ITOH*3, Koetsu YAMAZAKI and Jing HAN \\ ${ }^{* 3}$ Universal Can Corporation, \\ 1500 Suganuma, Oyama-cho, Sunto-gun, Shizuoka, 410-1392 Japan
}

\begin{abstract}
This paper studied factors that affect consumers' feeling in fingers when unscrewing the cap to open an aluminum beverage bottle, and then investigated experimentally and numerically the size and surface shape of the cap in order to guarantee consumers' openability. Firstly, the gripping and opening way while rotating the cap by fingers was determined as the most popular opening way according to a survey of consumers. The grip force and torque were then measured simultaneously using an experimental bottle equipped with force sensors, and the relationships between the gripping force of fingers and the torque, the dimension and the gripping force of human hands were investigated. Moreover, experiments of semantic differential method were performed to study feelings in finger when pressing vertically and then moving along the surface of test pieces. It's observed that the dimensions of the surface in a wave-shape influenced the feeling in finger as well as the slip between the finger and the test piece. Finally, a finite element analysis model of finger pressing and moving along the wave-shape rigid surface was examined to evaluate numerically the discomfort and slip.
\end{abstract}

Key Words: Biomechanics, Emotion, Kansei and Embodiment, Human Engineering, Product Design

\section{1. 緒}

一般市場における飲料容器には，ビールに代表され るアルミ缶, 缶コーヒーに代表されるスチール缶, 牛 乳に使用される紙パック，栄養ドリンクに使用される 小形瓶, 清涼飲料に使用されている PET ボトルやア ルミボトルなどさまざまな容器がある，それぞれの容 器には要求される機能や品質があり, 金属や樹脂の成 形技術, 容器の耐食性や意匠性のための塗装・印刷技 術など，の総合的な技術を駆使して発展を続けてい る(1)(2).アルミボトルは 2000 年ごろに PET ボトルと 同様にキャップでの再栓ができるアルミ缶として上市 された(3). 再栓可能なキャップが付いた容器では, 材 料として樹脂製やアルミニウム製のものや, 飲みロが 小さいものから大きいものまで多種多様な容器が存在 している．消費者が飲料を飲む前の最初の動作が密封 解除であり，アルミ缶やスチール缶は缶蓋に取付けら れたタブと称するヒンジ部を引上げて開ロし, アルミ

\footnotetext{
* 原稿受付 2007 年 6 月 11 日.

*1 正員, ユニバーサル製缶(株)商品開発部( 410-1392 静岡 県駿東郡小山町菅沼 1500).

*2 正員, 金沢大学大学院自然科学研究科( 920-1192 金沢市 角間町).

E-mail : itoh@unican.co.jp
}

ボトルやPET ボトルはキャップをねじって開ロす る.アルミボトルのキャップは図 1 に示すように缶胴 口部に成形されたねじ部にキャップが取付けられて密 封性を保っている、キャップには開栓時に滑りを抑え るためのナールと称する凹凸部なども付与している. 開栓時にはキャップをねじる力 (以下開栓トルクと表 記）を負荷するとキャップが回転を始め，その後にい たずら防止のために付与されているスカート部とキャ ップのねじ部を締結しているミシン目状のブリッジ部 をキャップの回転に伴って破断して開栓する機構とな っている(4)(5).

近年, 飲料容器では一般工業製品と同様に使いやす さに関する要求が強くなっている.アルミボトルの使

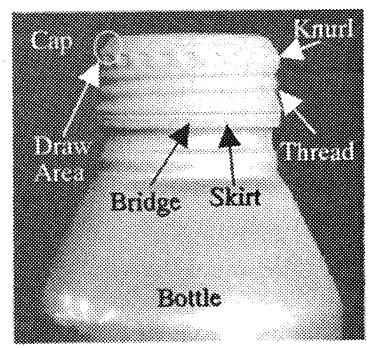

Fig. 1 An aluminum bottle with cap 
いやすさには，開栓しやすさや飲みやすさなどがあ る、著者らはアルミボトルの飲みやすさの検討に感性 工学手法を適用し, 飲みやすさには飲み口から出てく る内容液の流量と容器の調節性が影響することなどを 明らかにした(6).また，口径を含むボトル諸元と開栓 特性について力学的検討を行い，口径を小さくすると 開栓トルクが小さくなることを初等解析等から明らか にした(5).しかし，開栓時の開栓トルク值に着目した 研究(7)(8), 手の大きさと締付け力に関する研究(9)など は見受けられるが，その他の開栓しやすさに影響を及 ぼす要因の詳細な検討は見受けられない。そこで, 本 研究ではキャップの開栓動作を手で開栓トルクを負荷 するのみならず, 手でキャップを握り，滑らないよう に, 開栓トルクを負荷するとして詳細な検討を行っ た．具体的には開栓時のキャップの握り方，ロ径・手 の大きさ・開栓トルクとキャップ握り力の関係，キャ ップの凹凸形状と痛感・滑り性について検討を行っ た.これらの結果から,アルミボトルの開栓しやすさ の方向性を示す.

\section{2. キャップの握りカ}

一般的に缶胴・キャップの開栓動作（右利きの場合） は左手で缶胴を保持し, 右手でキャップを握り, 缶胴 とキャップをねじることによって開栓する．開栓時に 缶胴とキャップをねじるためには，手と缶胴・キャッ プとの摩擦があることによって滑らずに開栓できる。 この摩擦は缶胴およびキャップを握る力(面圧)と凹凸 によって決定される。この握る力は手の大きさや対象 物の大きさにより力の入りやすさに違いがあるといわ れているが, アルミボトルロ部(キャップ)の力の入り やすさについて検討した研究は見当たらない.そこ で,アルミボトルのロ径を種々変更した場合のキャッ プ握り力の測定を行った.

$2 \cdot 1$ キャップの握り方 ボトルの開栓動作を行 う場合, 消費者は種々の握り方をするといわれてい る.開栓時の握り方の代表的な例を図 $2(\mathrm{a}) \sim(\mathrm{c})$ に
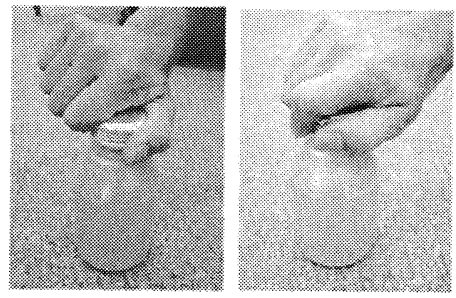

(a) Grip method 1 (b) Grip method 2 (c) Grip method 3

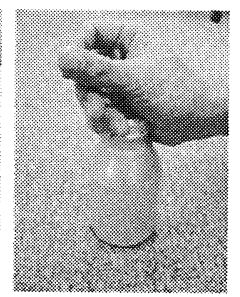

(a) Grip method 1 (b) Grip method 2 (c) Grip method 3

Fig. 2 Gripping postures for cap opening
示す。図2( $\mathrm{a}$ ) は拇指と食指でキャップを挟み, 図 2(b)は拇指と中指でキャップを挟み，食指を添える 握り方, 図 2(c) は掌と薬指でキャップを挟む握り方 である. 男子学生 127 名, 女子学生 122 名によるアン ケート調查を行った結果，図 2(a) の握り方で約 21\%, 図 2(b) の握り方で約 $43 \%$ となり，この両者で約 $64 \%$ を占めていることがわかった。この結果より，消費者 はキャップの握り方として, 拇指と食指もしくは中指 でキャップを挟み込む握り方が大半を占め，キャップの 直径方向に挟み込む力を負荷していることがわかった。

$2 \cdot 2$ 手の大きさと握力 一般的に握りやすさや 力の入りやすさには, 手の大きさが関係しているとい われている。そこで, 飲料容器であるアルミボトルの 一般的な口径においても同様な状況にあるかを確認し た. 20 歳代から 50 歳代の男性 65 名, 女性 25 名を被 験者とし，手の大きさと筋力を示す握力等の測定を行

Table 1 Hand and arm dimension, gripping power

\begin{tabular}{c|c|c|c|c}
\hline & ave. & max. & min. & SD \\
\hline Palm width & 85.3 & 92 & 75 & 3.99 \\
$W_{p}(\mathrm{~mm})$ & 75.9 & 80 & 72 & 2.80 \\
\hline Plam height & 99.7 & 110 & 86 & 5.18 \\
$H_{p}(\mathrm{~mm})$ & 92.2 & 103 & 81 & 5.05 \\
\hline First finger & 72.4 & 82 & 60 & 4.04 \\
length $L_{1}(\mathrm{~mm})$ & 68.6 & 75 & 60 & 3.89 \\
\hline Middle finger & 79.9 & 90 & 70 & 4.52 \\
length $L_{2}(\mathrm{~mm})$ & 76.2 & 82 & 71 & 2.95 \\
\hline Third finger & 73.8 & 87 & 62 & 4.48 \\
length $L_{3}(\mathrm{~mm})$ & 69.9 & 77 & 62 & 3.46 \\
\hline Little finger & 58.4 & 67 & 50 & 4.41 \\
length $L_{l}(\mathrm{~mm})$ & 55.8 & 65 & 48 & 4.12 \\
\hline Thumb length & 62.5 & 73 & 55 & 3.61 \\
$L_{t}(\mathrm{~mm})$ & 58.1 & 67 & 50 & 3.53 \\
\hline Circle length & 156.8 & 177 & 140 & 8.44 \\
$D_{i}$ (mm) & 150.0 & 160 & 135 & 8.19 \\
\hline Arm thickness & 271.3 & 320 & 239 & 17.69 \\
$L_{a}(\mathrm{~mm})$ & 227.6 & 261 & 206 & 13.18 \\
\hline Gripping power & 461.5 & 598 & 294 & 66.7 \\
$P_{a}$ (N) & 274.4 & 378 & 147 & 62.4 \\
\hline \multicolumn{4}{|l}{}
\end{tabular}
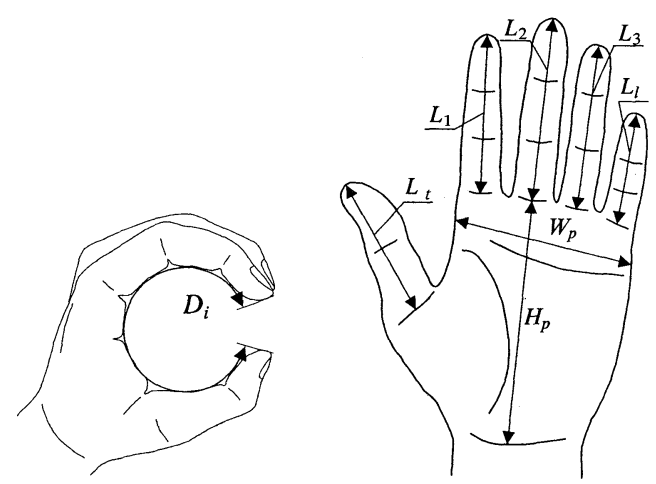

Fig. 3 Hand dimensions 
った. 手の大きさの指標として, 手の平幅 $W_{p}$, 手の 平高さ $H_{p}$, 食指長さ $L_{1}$, 中指長さ $L_{2}$, 薬指長さ $L_{3}$, 小指長さ $L_{l}$, 拇指長さ $L_{t}$, 拇指と食指の握り内径 $D_{i}$ を測定した(図 3). また, キャップ握り力には力の強 さを示す握力 $P_{a}$ や筋肉の太さを示す前腕最太部の周 長 $L_{a}$ (时と手首間の最太部であり, 以後, 前腕周長と 表記も影響していると考え，この両者も測定した。 各測定結果を表 1 に示す. 表中には各諸元の平均值 (ave.), 最大值 (max.), 最小值 (min.), 標準偏差 (SD) を示しており，上段は男性の，下段は女性の計測值を それぞれ示している.この測定結果より，男性と比較 して女性の手の大きさは平均的に男性の約 $94 \%$, 前腕 周長は約 $84 \%$, 握力は約 $60 \%$ であることがわかった. 女性では手の大きさより, 握力の弱さが際立つことが わかった。

\section{$2 \cdot 3$ 口径とキャップ握りカの関係 消費者がア} ルミボトルの開栓を行う場合, 図 2 に示すようにキャ ップを握りながらねじって開栓を行う.キャップを握 る場合の挟み込み力を計測するため, キャップ部位の みを二分割してスリットを設け，そのスリット部に薄 形力センサ(KISTLER 社製 9132 B) を挟み込み, 直 径方向のキャップ握り力を測定する装置を製作した (キャップ部単独では回転しない機構)。このキャップ 握り力とはキャップを指で握る力であり, キャップの 円周上の直角方向 2 箇所に作用する半径力である. キ ヤップ部にはアタッチメントとして $\phi 28, \phi 33, \phi 38$, $\phi 43 \mathrm{~mm}$ 口径の 4 種類を準備し, 口径ごとのキャップ 握り力を測定できるようにした. 口径の種類は容器コ ストや飲みやすさ ${ }^{(6)}$ の観点から飲料容器で一般的な $\phi 28 \sim \phi 43 \mathrm{~mm}$ 口径の範囲で検討することとした.

手の大きさ等を測定した被験者にて, このキャップ 握り力測定ジグを用い, 各口径のキャップ握りカを測

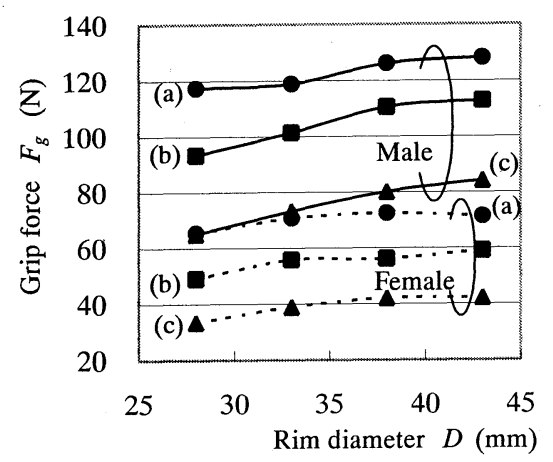

Fig. 4 Relation between maximum grip force and rim diameter
定した.キャップ握り力の測定では図 2 に示す 3 種類 の握り方で各口径 3 回ずつ, 力一杯握った力を測定し た. 各口径のキャップ握り力測定結果を図 4 に示す. 図 4 において実線は男性，破線は女性のキャップ握り 力 (平均值)を示し, 図中記号の ( a ), (b), (c) は図 2 に示す握り方にそれぞれ対応している. 図 4 より, 男 性と女性では, 女性のほうがキャップ握り力は弱く, 男性の約 $60 \%$ のキップ握り力であり, 握力の男女差 と同等比率であることがわかった. 各握り方では図 2(a)に示す拇指と食指でキャップを挟む握り方のキ ヤップ握りカが最も強く, 図 2(b), (c) の順に弱く なり，この傾向は男女ともに同一であった，また，検 討範囲内での口径の影響として, 男性は口径が大きく なるとキャップ握り力も大きくなる傾向を示し, 口径 が大きいほど力が入りやすい結果となった。しかし， 女性の場合, 口径が小さい場合はキャップ握り力が小 さくカが入りづらい傾向を示すが, 口径 $33 \mathrm{~mm}$ 以上 の検討範囲内ではほほ同等のキャップ握りカとなり, 力の入りやすさに影響しないことがわかった. 女性被 験者に口径が変わってもキャップ握り力が変わらない 理由を確認したところ, ある程度の力で握ると指に痛 感を覚えてそれ以上に強く握ることを止めている場合 のあることがわかった.

このことより,アルミボトルのキャップではロ径が 大きいほど力が入りやすい傾向を示すことがわかっ た.しかし，女性では，口径 33 から $43 \mathrm{~mm}$ 間で力の 入りやすさに変化はなく, キャップ握り力の上限には 指の痛感が影響を与えることがわかった。これは女性 のほうが痛覚に関するしきい值が低いためと考えられ

Table 2 Pearson's correlation procession

\begin{tabular}{c||c|c||c|c|c}
\hline & $L_{a}$ & $P_{a}$ & $F_{g(a)}$ & $F_{g(b)}$ & $F_{g(c)}$ \\
\hline \multirow{2}{*}{$W_{p}$} & $\mathbf{0 . 5 6 2}$ & $\mathbf{0 . 3 8 5}$ & 0.149 & 0.171 & 0.082 \\
& 0.227 & 0.328 & 0.344 & 0.385 & 0.219 \\
\hline \multirow{2}{*}{$H_{p}$} & 0.182 & $\mathbf{0 . 3 6 0}$ & 0.171 & 0.117 & 0.048 \\
& $\mathbf{0 . 4 4 2}$ & 0.214 & 0.188 & 0.253 & 0.241 \\
\hline \multirow{2}{*}{$L_{1}$} & 0.062 & $\mathbf{0 . 4 0 7}$ & 0.049 & -0.056 & 0.026 \\
& 0.346 & 0.053 & 0.333 & 0.224 & -0.083 \\
\hline \multirow{2}{*}{$L_{2}$} & 0.013 & $\mathbf{0 . 3 2 9}$ & 0.079 & -0.034 & -0.055 \\
& 0.107 & 0.060 & 0.155 & 0.150 & 0.015 \\
\hline \multirow{2}{*}{$L_{3}$} & -0.118 & 0.196 & -0.071 & -0.179 & -0.090 \\
& 0.043 & 0.258 & 0.268 & 0.206 & -0.046 \\
\hline \multirow{2}{*}{$L_{l}$} & -0.070 & $\mathbf{0 . 2 5 3}$ & -0.025 & -0.131 & -0.117 \\
& 0.092 & $\mathbf{0 . 4 2 2}$ & 0.315 & 0.249 & -0.012 \\
\hline \multirow{2}{*}{$L_{t}$} & -0.020 & $\mathbf{0 . 3 1 4}$ & 0.229 & 0.133 & 0.140 \\
& 0.343 & 0.047 & -0.136 & -0.227 & -0.211 \\
\hline \multirow{2}{*}{$D_{i}$} & -0.121 & 0.275 & 0.126 & -0.008 & 0.075 \\
& 0.183 & -0.013 & 0.233 & 0.232 & 0.096 \\
\hline \multirow{2}{*}{$L_{a}$} & - & $\mathbf{0 . 3 7 4}$ & $\mathbf{0 . 2 9 1}$ & $\mathbf{0 . 3 3 4}$ & 0.080 \\
& & 0.056 & 0.009 & 0.053 & -0.033 \\
\hline \multirow{2}{*}{$P_{a}$} & & - & $\mathbf{0 . 5 2 7}$ & $\mathbf{0 . 5 1 7}$ & $\mathbf{0 . 3 2 1}$ \\
& & - & 0.357 & 0.357 & 0.179 \\
\hline \multirow{2}{*}{$\quad$}
\end{tabular}


$ろ^{(10)}$.

$2 \cdot 4$ 手の大きさとキャップ握りカの相関 $2 \cdot 3$ 節 で口径とキャップ握り力の関係が把握できたので, 本 節では手の大きさとキャップ握り力の関係を検討した 結果を示す.キャップ握り力測定前に計測した手の大 きさ, 握力, 前腕周長とキャップ握り力の関係を明確 にするため各計測值間の相関を確認した。すべての口 径を含めた各項目の Pearson 相関行列を表 2 に示す. 表 2 には手各部の寸法と図 2(a)，（b)，（c）に示し た各握り方でのキャップ握り力をそれぞれ $F_{g(a)}$, $F_{g(b)}, F_{g(c)}$ として表記した。 また, 表中の上段は男性 の，下段は女性の相関係数をそれぞれ示している.表 中の相関係数として太字斜体で表記した数值は被験者 の標本数にて $5 \%$ の有意性検定を行い, 相関ありと判 定されたものである (男性検定值 0.246 , 女性検定值 0.403). 表 2 より, 男性では手の各寸法と前腕周長 $L_{a}$ やキャップ握り力 $F_{g(a)}, F_{g(b)}, F_{g(c)}$ に相関はなく, 握力 $P_{a}$ に弱い相関がある. 一方, 女性では手の各寸 法と前腕周長, キャップ握り力, 握力に相関はない. また，表 2 は全口径を含めた相関係数であるが，口径 ごとの相関有無の傾向は同様であった。これらのこと より, 手の大きさとキャップ握り力には相関のないこ とがわかった. キャップ握り力と相関のあるのは, 男 性では握力 $P_{a}$ と前腕周長 $L_{a}$ であり, 握力とは強い 相関, 前腕周長とは弱い相関がある。このことはキャ ップを握るときに作用する筋肉と握力を計測するとき に作用する筋肉はほほ同一(时と手首間における長掌 筋, 腕橈骨筋, 浅指屈筋など) であると考えられ, 筋力 が強いことは筋肉が太いこととおおむね同様であるこ とから, 前腕周長にも相関があるものと考えられる。 女性ではキャップ握り力と握力や前腕周長などに相関 のない結果となった. 本来, 女性においても筋力が強 いほうがキャップ握り力も強くなると考えられるが, 前述した痛感によって握ることを抑制したため, 相関 が得られなかったと考えられる。

\section{3. 開栓トルクとキャップの握りカ}

$3 \cdot 1$ 開栓トルクとキャップ握りカの関係 開栓 時のトルクとキャップ握り力を測定するため, キャッ プ握り力測定ジグを手動開栓トルク測定器 (日本電産 シンポ社製 TNK-50 B-1)に設置し, 開栓トルク測定 と同時にキャップ握り力を測定した.

女性被験者で $\phi 38$ 口径ジグ, 図 2(a) の握り方にて 測定したキャップ握り力と開栓トルクの関係の典型的 な一例を図 5 に示す。図 5 より開栓トルク $T r$ の増加 とともにキャップ握り力 $F_{g}$ もきくなり, 開栓トル
クを弱めるとキャップ握り力も小さくなっていること がわかった．このようにアルミボトルのキャップを開 栓する場合, 消費者はキャップに開栓トルクを加える とともに，握っている指が滑らないようにキャップ握 りカを強めるよう調整していると考えられる.したが って，消費者は開栓トルクが高い場合では，ねじる力 が大きいだけでなく握る力も大きくなると考えられ る.

$3 \cdot 2$ 口径の影響 口径が開栓トルクとキャップ 握り力の関係に与える影響を確認するため, 女性被験 者 4 名にて $\phi 28, \phi 33, \phi 38, \phi 43$ 口径のアタッチメ ントを用いて図2(a)の握り方で, それぞれ 3 回の測 定を行った。各計測結果として得られた最大トルクと 最大トルク発生時のキャップ握り力の平均值を図 6 に 示す. 図 6 より，口径が小さいほど被験者が負荷でき るトルクは小さくなり, キャップ握り力は $\phi 33$ 口径 以下の検討範囲内で小さくなることがわかった。この キャップ握り力は図 4 で示した，ねじらずに握るだけ の傾向と同様であった．今回の計測に用いた各口径ア タッチメントには滑り止めとなる凹凸を付けていない ため，滑りやすい状態で被験者が負荷できるトルクを

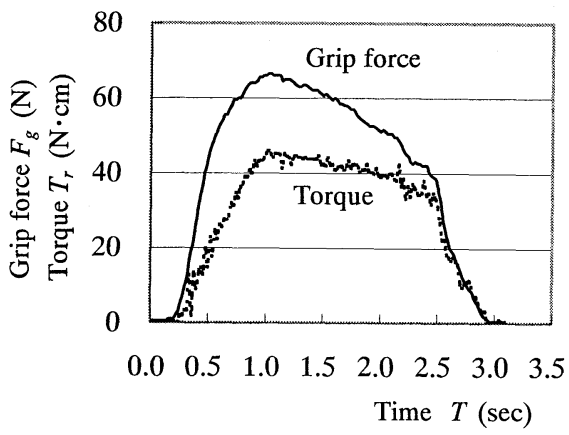

Fig. 5 Chart of grip force and torque

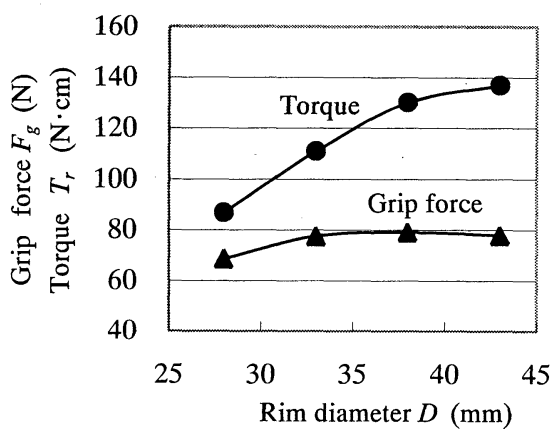

Fig. 6 Relation between grip force, torque and rim diameter 
得ており，摩擦が最も少ない状態で得られるトルクで ある。この結果を考慮すると開栓トルクの目標值は測 定された最大トルクのばらつきの最小值以下にすべき と考えられる。 $\phi 28, \phi 33, \phi 38, \phi 43$ 口径の最小値 はそれぞれ 40.8, 54.0, 61.6, $57.2 \mathrm{~N} \cdot \mathrm{cm}$ であるが, これらの值は非常に小さく, 目標とするには他の課題 (密封性など(5))が問題となる。 そこで, 力の弱い女性 を被験者とし，滑り止めとなる凹凸のない状態での各 口径の最大トルク值以下(図 6)にすることが現実的な 目標になると考えられる.

開栓時にキャップが回転を始めるときのトルク $T_{r}$ の釣合いは $T_{r}=D \cdot \mu \cdot F_{g}$ で示される.ここで, $D$ は 口径, $F_{t}$ はトルク負荷時の接線力, $\mu$ は指とキャップ の見掛けの摩擦係数, $F_{g}$ はキャップ握りカである. この式に抢ける右辺が左辺より大きい場合は滑らずに 開栓でき, その逆の場合は滑って開栓できないことを 示している. 消費者はこの滑りを回避するため, 図 5 に示すようにキャップ握りカ $F_{g}$ を調整することにな る. 上式と本実験結果を用いて, 口径ごとに算出した 摩擦係数 $\mu$ を表 3 に示す。この結果より, 口径が小さ いほど必要となる摩擦係数は大きくなる傾向を示すこ とがわかった。これは, 口径が小さいと作用半径が小 さくなるため負荷できるトルクは小さくなるが, その 影響以上に力の入りやすさの影響を受けて, 負荷でき るキャップ握りカも小さくなるため, 大きな摩擦係数 が必要になるためである.

このことから, 開栓トルクが図 6 に示す值であれば, 消費者が負荷できるトルクと力の入りやすさを考慮す ると, 口径が大きいほど官能的に開栓しやすいと考え られる. 開栓トルクが高い場合には, 摩擦係数 $\mu$ を大 きくするか, キャップ握りカ $F_{g}$ を大くする必要が ある. しかし, 力の弱い女性, 高齢者, 子供などでは 本検討結果以上の握り力を負荷することは期待できな い.そこで, 摩擦を大きくすることが必要となり，2 章での検討結果からキャップを握る力に痛感が影響を 与えるため, 凹凸形状と痛感の関係を考慮することが 重要となる.

\section{4. キャップの凹凸形状と痛感}

3 章までに口径がキャップ握りカに与える影響を確 認した. キャップ握りカが大きい場合には痛感を覚え やすくなり,アルミボトルを開栓しにくいと感じる可 能性がある。この痛感には加える力の大きさだけでな く, キャップに成形されているナールと称する凹凸部 形状の影響があると考えられるため, 人の指と凹凸形 状による滑りやすさと痛さの関係を検討した。

4・1 凹凸形状による官能試験 凹凸形状が滑り やすさと痛感にどのような影響があるかを確認するた め, 30 名の女性被験者に 5 種類の凹凹形状を付けた平 面試験片を握ってもらい, 握ったときの痛さと握った 状態での滑りやすさに順位付けを行う官能試験を行っ た.今回用いた試験片は縦 $30 \mathrm{~mm}$, 横 $50 \mathrm{~mm}$, 高さ $20 \mathrm{~mm}$ の樹脂製立方体の縦横平面に図 7 および表 4 に示す凹凹形状を施したものとした. 表 4 の 5 種類の 形状は市販飲料容器に用いられる樹脂製やアルミニウ

Table 4 Dimensions of knurled test piece

\begin{tabular}{c|c|c|c|c}
\hline $\begin{array}{c}\text { Test } \\
\text { piece } \\
\text { No. }\end{array}$ & $\begin{array}{c}\text { Radius } \\
R_{a}(\mathrm{~mm})\end{array}$ & $\begin{array}{c}\text { Pitch } \\
p(\mathrm{~mm})\end{array}$ & $\begin{array}{c}\text { Depth } \\
d(\mathrm{~mm})\end{array}$ & $\begin{array}{c}\text { Angle } \\
A_{1}, A_{2}(\mathrm{deg})\end{array}$ \\
\hline 1 & 0.5 & 2.5 & 0.84 & 45 \\
\hline 2 & 0.2 & 2.5 & 1.08 & 45 \\
\hline 3 & 0.5 & 2.5 & 0.42 & 45 \\
\hline 4 & 0.5 & 5.0 & 1.04 & 45 \\
\hline 5 & 0.2 & 1.25 & 0.68 & 30 \\
\hline
\end{tabular}

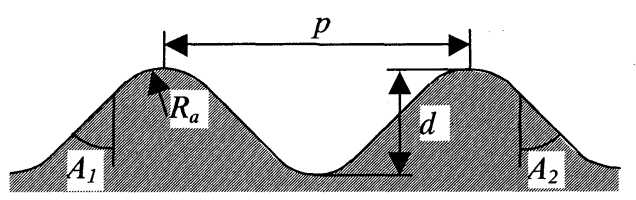

Fig. 7 Surface shape of test pieces

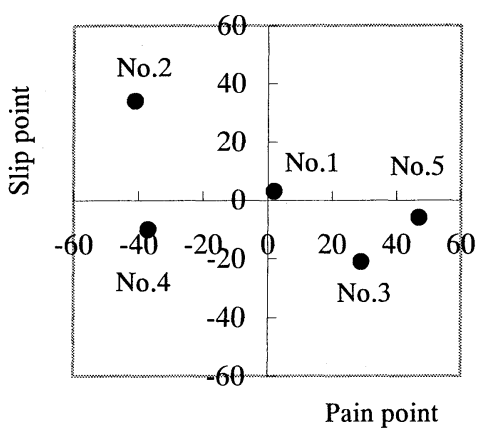

Fig. 8 Experimental results of semantic differential method 
ム製キャップの一般的なナール部の凹凸を模擬してい る。この試験では, 男性より痛感のしきい值が低いと される女性のみを被験者とし, 握り方も実際のキャッ プを握ったときとほほ同位置(食指の拇指側側面)が試 験片の凹凸に接触するようにして評価させた。

官能試験結果から得られた痛さと滑りやすさの順位 にそれぞれ点数付け $(1$ 位に 2 点, 2 位に 1 点, 3 位に 0 点, 4 位にー 1 点, 5 位にー2 点)を行った。評価結果を 図 8 に示す. 図 8 では点数の小さいほうが痛く, 滑る 表記としている. 官能的に最も痛くないと感じられた のはNo. 5 形状であり, 痛いと感じられたのはNo. 2 もしくはNo. 4 であった. また, 滑りにくいと感じら れた形状はNo. 2 であり, 滑りやすいと感じられたの はNo. 3 もしくはNo. 4 であった。本来, キャップを 開栓しやすくするためには, 図 8 における第 1 象限の 右上が好ましい. 今回試験した一般的な市販キャップ のナール部を模擬した形状には, 痛さと滑りやすさの 両方に優れた形状はなく，この両者は相反する特性に なっていると考えられる。そこで，これら形状諸元の 影響度を確認するため, 表 5 にそれぞれの Pearson 相 関係数を示す. 表中の相関係数として太字斜体で表記 した数值は被験者の標本数で $5 \%$ の有意性検定を行い, 相関ありと判定(検定值 0.161) されるものであり, 痛 さ，滑りやすさについては数值が大きいほどそれぞれ 痛くない, 滑らないことを示している。痛さについて は形状的に深さ $d$, 角度 $A$, ピッチ $p$ に強い相関が認 められ，指が凹凸形状に食込む量が増加すると指の痛 点を刺激しやすくなるため, 痛みを感じやすくなると 考えられる.また, 滑りやすさについては, ピッチ以 外で相関が認められるが, 相関は弱い. 傾向的には, 指に引つ掛かる個数よりも形状的な一山当たりの引っ 掛かり抵抗が影響するといえる。

したがって，キャップを握る場合の痛感性や滑り性 には山凹形状の影響があることが明確となり，凹凸形 状の適正化によって開栓するときの不快感や痛みを低 減できる可能性のあることがわかった。

\section{5. 痛感性, 滑り性の解析的検討}

人の触覚に関する研究は認知科学として種々の検討

Table 5 Pearson's correlation procession

\begin{tabular}{c|c|c}
\hline & Pain & Slip \\
\hline Radius $R_{a}$ & -0.003 & -0.291 \\
\hline Pitch $p$ & -0.584 & -0.067 \\
\hline Depth $d$ & -0.744 & 0.289 \\
\hline Angle $A$ & $\mathbf{- 0 . 7 3 3}$ & $\mathbf{0 . 2 6 4}$ \\
\hline
\end{tabular}

がなされてきており, 指部の解析的検討もロボット工 学などの分野で行われている(11). また, 指部の力学的 特性を把握するために解析的な研究(12) なども行われ ているが, 痛感との関係を検討した研究は見受けられ ない. そこで, 以下に示す手法にて指部の痛感性や滑 り性の解析的な検討を行った。

$5 \cdot 1$ 解析モデル 痛感を解析的に検討するには 指の構造を理解する必要がある。指は表層から表皮, 真皮, 皮下組織, 指骨で構成され, 表皮はさらに表層 から角質層, 顆粒層, 有棘層, 基底層がある。指内に は各種刺激の受容体として, 機械的刺激を受容するメ ルケル細胞, 振動や軽い接触を受容するマイスナー小 体, 大きな圧力や早い振動を受容するパチニ小体, 変 化の遅い機械的刺激を受容するルフィ二終末, 温感覚 や痛覚を受容する自由神経終末が内在していることが 知られている(12).

本解析では凹凹形状と痛感および滑り性に関する定 性的な方向性を確認することを目的に簡略化したモデ ル構成とした. 詳細な検討をするには三次元解析が必 要であるが, 指の機械的材料特性に異方性がないと仮 定すれば計算コストを考慮して図 9 に示す平面ひずみ 状態にモデル化できると考えた。このモデルでは指部 を弾性体, 凹凸形状部を剛体とした。指部の有限要素 分割は, キャップを握ったときの接触長さが約 30 $\mathrm{mm}$ であること, 表皮と真皮部に存在する自由神径終 末の変形を再現できるように人の痛点数(約 200 個 $/ \mathrm{cm}^{2}$ )を参考(13) として, 幅方向に 428 分割した(モ デル幅は $29.96 \mathrm{~mm})$. 皮下組織は変形が大きくない ため幅方向に 107 分割した。要素分割数は，表皮で 2140 個, 真皮で 3424 個, 皮下組織で 1712 個とした. 一般的な解析では凹凸のある剛体接触部で発生する応 力やひずみで評価を行うが, 本解析では痛覚を受容す

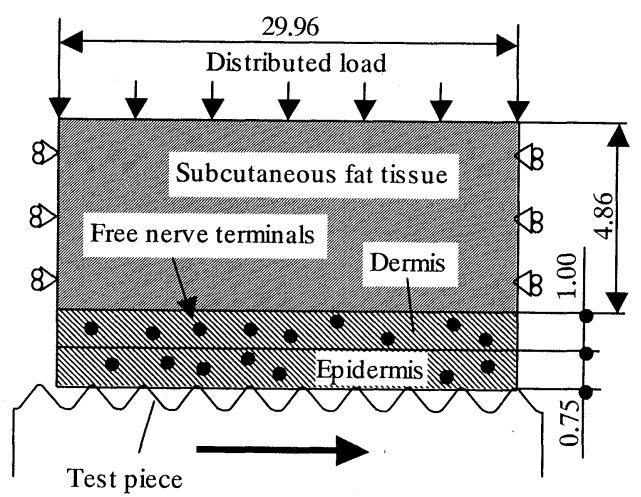

Fig. 9 Numerical analysis model 
る自由神経終末の存在する表皮(角質層厚さを 0.2 $\mathrm{mm}$ として除く) と真皮部の応力状態で評価すること を特徴とし, 表皮, 真皮, 皮下組織, 指骨にそれぞれの 機械的特性を与えた。それぞれの特性値は著者らが指 の圧縮試験から得た弾性体としての特性値 ${ }^{(14)}$ と前野 らの研究(12) で人新鮮死体から得た表皮, 真皮, 皮下組 織の弾性率比を用いて表 6 に示す値とした。 また, 解 析では摩擦をクーロン摩擦とし, 静摩擦係数 0.735 , 動摩擦係数 $0.70^{(15)}$ とした. 解析にははん用有限要素 コード MSC-MARCを用い, 指の厚さ方向の変位を 同一化した皮下組織の上部から分布荷重を負荷した 後, 凹凸形状のある剛体を凹凹の 1 ピッチ分移動させ る解析を行った。

$5 \cdot 2$ 解析の妥当性検討 解析手法や評価方法の 妥当性を確認するため,まず 4 章の検討において痛感 で大きく差異(図 8)のあったNo. 4 とNo. 5 形状およ び凹凸のない平坦形状について解析を行った，皮下組 織上部からの分布荷重はNo. 4 形状において, 実際の 指の食込み量がほほ同等となる負荷 $(2.9 \mathrm{MPa})$ とし た. 各形状モデルにおいて 1 ピッチ分移動させるとき に凹凸形状を付与した剛体が受ける滑り抵抗力を図 10 に示す. 図 10 では横軸をピッチとし, 緹軸には平 坦形状の場合の滑り抵抗力 $F_{f}$ との比で表記してい る.図 10 より, No. 4 と No. 5 モデルにおいて, 両者 の滑り抵抗力が平坦形状の約 7 倍から 8 倍になってお り, 平坦形状より滑り抵抗の大きいことが再現できて

Table 6 Mechanical properties of finger finite element model

\begin{tabular}{l|c|c}
\hline & $\begin{array}{c}\text { Young's } \\
\text { modulus } \\
\text { (MPa) }\end{array}$ & $\begin{array}{c}\text { Poisson's } \\
\text { ratio }^{(12)}\end{array}$ \\
\hline Subcutaneous fat tissue & 5.0 & 0.48 \\
\hline Dermis & 12.5 & 0.48 \\
\hline Epidermis & 20.0 & 0.48 \\
\hline
\end{tabular}

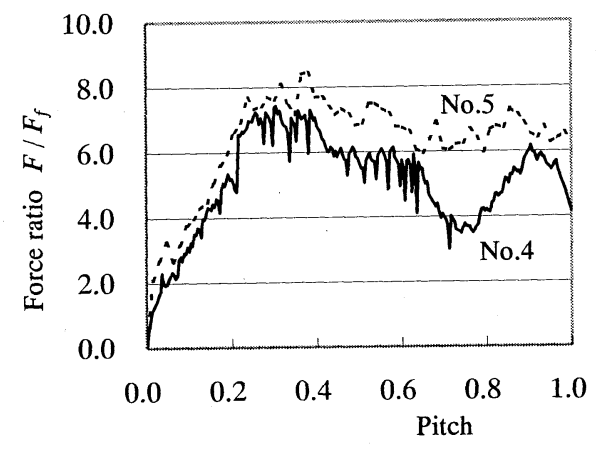

Fig. 10 Force ratio-pitch curve
いる.ささに, 両形状共に滑り抵抗力比の最大値はほ ぼ同様であり，図 8 に示す官能評価においても No. 4 とNo. 5 は滑り性がほぼ同等であることと合致してい る.

次に各形状での痛感を検討するため, 図 9 に示す解 析モデルにて指内の発生応力を確認した. 応力分布の 一例と形状諸元を図 11 に示す。この応力分布から凹 凸形状に接触している指表層で応力が高く, 隣接形状 の影響を受けて表層より内部で応力が干渉する部位が 存在していることがわかる. 指表層の角質層には痛み を受容する自由神経終末がないため, 接触部の最大応 力では痛感を検討できない.そこで, 自由神経終末の 存在する表皮(角質層を除く) と真皮に発生する最大相 当応力 $\sigma_{\max }$ を用い, 境界条件の影響を受けないよう にモデル幅の中心部 $1 / 3$ 領域で評価した. 最大相当応 力とピッチの関係を図 12 に示す. 図 12 では横軸に移 動ピッチ, 縦軸に平坦形状でのミ一ゼス最大相当応力 $\sigma_{f}$ との比を表記している. 図 12 より, No. 4 形状で は平坦形状の約 60 倍, No. 5 形状では約 26 倍の応力 となっている.このことは, 凹凹形状があることによ って, 指の変形が大きくなり痛覚を感じやすくなるこ とが再現できている。 また, 図 8 に示す官能評価にお いても No. 4 形状は痛いと感じるが, No. 5 形状は最 も痛くないとする評価を受けていることと合致してい る.したがって, 本解析は簡略化したモデルではある

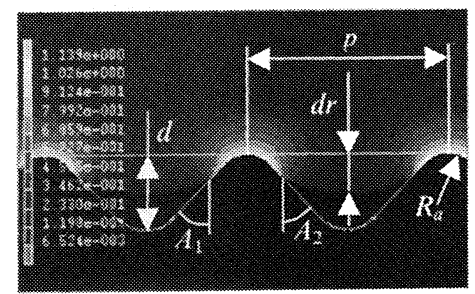

Fig. 11 Distribution of stress

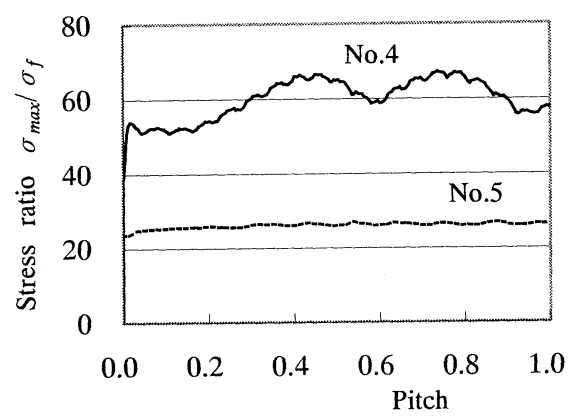

Fig. 12 Stress ratio-pitch curve 
Table 7 Dimensions and results of numerical models

\begin{tabular}{c|c|c|c|c|c|c|c|c}
\hline Model & $\begin{array}{c}\text { Radius } \\
R_{a} \\
(\mathrm{~mm})\end{array}$ & $\begin{array}{c}\text { Pitch } \\
\begin{array}{c}p \\
(\mathrm{~mm})\end{array}\end{array}$ & $\begin{array}{c}\text { Depth } \\
d \\
(\mathrm{~mm})\end{array}$ & $\begin{array}{c}\text { Angle } \\
A_{1} \\
(\mathrm{deg})\end{array}$ & $\begin{array}{c}\text { Angle } \\
A_{2} \\
(\mathrm{deg})\end{array}$ & $\begin{array}{c}\text { Deforma- } \\
\text { tion } \\
d_{r}(\mathrm{~mm})\end{array}$ & $\begin{array}{c}\text { Force } \\
\text { ratio } \\
F / F_{f}\end{array}$ & $\begin{array}{c}\text { Stress } \\
\text { ratio } \\
\sigma_{\max } / \sigma_{f}\end{array}$ \\
\hline $\mathrm{M} 1$ & 0.5 & 5.0 & 1.04 & 45 & 45 & 1.04 & 7.43 & 67.22 \\
\hline M2 & 0.2 & 1.25 & 0.68 & 30 & 30 & 0.19 & 8.46 & 27.18 \\
\hline M3 & 0.5 & 3.0 & 1.04 & 45 & 45 & 0.51 & 8.11 & 40.01 \\
\hline M4 & 0.5 & 7.0 & 1.04 & 45 & 45 & 1.04 & 9.81 & 66.16 \\
\hline M5 & 0.5 & 5.0 & 0.52 & 45 & 45 & 0.52 & 4.26 & 38.21 \\
\hline M6 & 0.2 & 1.25 & 0.39 & 30 & 60 & 0.18 & 6.00 & 23.37 \\
\hline M7 & 0.2 & 1.25 & 0.39 & 60 & 30 & 0.18 & 6.74 & 25.01 \\
\hline M8 & 0.5 & 1.25 & 0.48 & 30 & 30 & 0.14 & 3.16 & 16.04 \\
\hline
\end{tabular}

Table 8 Pearson's correlation procession

\begin{tabular}{c|c|c|c}
\hline & $\begin{array}{c}\text { Deformation } \\
d_{r}(\mathrm{~mm})\end{array}$ & $\begin{array}{c}\text { Force ratio } \\
F / F_{f}\end{array}$ & $\begin{array}{c}\text { Stress ratio } \\
\sigma_{\text {max }} / \sigma_{f}\end{array}$ \\
\hline Radius $R_{a}$ & 0.64 & -0.12 & 0.54 \\
\hline Pitch $p$ & $\mathbf{0 . 9 3}$ & 0.38 & $\mathbf{0 . 9 0}$ \\
\hline Depth $d$ & $\mathbf{0 . 8 2}$ & $\mathbf{0 . 6 9}$ & $\mathbf{0 . 8 4}$ \\
\hline Angle $A_{1}$ & 0.33 & 0.24 & 0.36 \\
\hline Angle $A_{2}$ & 0.33 & 0.10 & 0.32 \\
\hline
\end{tabular}

が, 指肉の引っ掛かりで表現される滑り性と自由神経 終末付近の変形からくる痛みを応力で評価したものが 官能評価結果とほほ一致し，解析モデルと評価方法は 妥当であることが確認できた。

$5 \cdot 3$ 凹凸形状の影響 解析の妥当性が確認でき たため, 凹凸形状が滑り抵抗力や発生応力に与える影 響を確認した。表 7 に対象とした解析モデルの凹凹形 状諸元および解析から得られた指肉の食込み量 $d_{r}$, 滑り抵抗力比 $F / F_{f}$, 最大相当応力比 $\sigma_{\max } / \sigma_{f}$ を示す. 表 7 のモデル形状は実際の飲料用キャップのナール部 に採用できる形状を考慮し(成形性など)，さらに，凹 凸の左右角度の影響を確認するための形状を選定し た. 解析モデル M 1 とＭ２は表 3 で示した実験モデ ルNo. 4, No. 5 形状に相当している. 表 8 にそれぞ れの Pearson 相関係数を示す. 表中の相関係数とし て太字斜体で表記した数値は解析值から $5 \%$ の有意性 検定を行い，相関ありと判定(検定値 0.69)されるもの である.この結果より, 指肉の食込み量 $d_{r}$ と応力比 $\sigma_{\max } / \sigma_{f}$ にはピッチと深さが大きく影響し, 滑り抵抗 力比 $F / F_{f}$ には凹凹深さの影響することがわかった。 発生応力は凹凸のピッチが小さいと指肉が凹凸に食込 む変形が小さくなるため発生応力も小さく，結果的に 自由神経終末の刺激が少なく, 痛感は少なくなると考 えられる．指の滑り抵抗は凹凸の深いほうが指の食込 み量が大きくなることによって見掛けの滑り抵抗が大 きくなると考えられる。

一般的に指の痛感には形状の鋭さが大きく影響する と考えられるが, 本研究結果では凹凹形状の先端半径
$R_{a}$ よりも凹凸のピッチ $p$ や深さ $d$ による指の変形の 影響が大きいことがわかった，指の痛感を少なくする ためには凹凹形状のピッチを小さくすることが好まし く，ピッチを小さくできない場合には凹凸深さを浅く することが効果的である。また，指の滑り抵抗を大き くするには凹凹を深くすることが効果的であるが，凹 凸深さを深くすると指の発生応力も高くなり痛感が大 きくなるため，この両者の適正化が重要であることが わかった。凹凸形状と痛感性および滑り性について は, 官能評価で得られた結果(表 5) と解析結果 (表 8) では相関の強さが多少異なる結果となったが, 官能評 価結果としての痛さや滑りやすさの順位, 影響度が大 きいと考えられる凹凸のピッチと深さについては本解 析と同様な結果が得られているので, 設計改善のため に示唆される方向性は十分に信頼できる。なお，詳細 な形状効果は多変量解析手法などを用いることによっ て明確になる可能性があるが, 今後の課題とする.

\section{6. 結 言}

本研究では飲料用アルミボトルの開栓しやすさを検 討するため, 開栓しやすさに及沽す主要因を(1)キャッ プの握り力, (2)キャップの開栓トルク, (3)指とキャッ プの滑り性の三つと考えた。これらの要因を確認する ため, 開栓時のキャップの握り方, 口径・手の大き さ・開栓トルクとキャップ握り力の関係, キャップの 凹凸形状と痛感・滑り性について検討を行い, 以下の 知見を得た。

人間工学的視点からアルミボトルの開栓性を良好に するには，口径によって力の入りやすさ・負荷できる トルクが異なるため, 口径ごとの適正開栓トルク以下 に開栓トルクを設計・設定することが重要である，実 際の開栓トルクが女性(力の弱い)の負荷できる最大の トルクと同等と仮定した場合, 口径と最大握り力(力 の入りやすさ)との関係から，口径が大きいほど開栓 しやすくなることが明確となった. 実際の開栓トルク 
が女性の負荷できる最大トルクより大きい場合, 開栓 はしづらくなる。開栓トルクが大きい場合や開栓トル ク低減以外で効果的に開栓しやすくするためには，キ ヤップ握り時の指痛感を低減させるために凹凸形状の ピッチを小さく, 深さを浅くすること, 指の滑りを抑 制するために凹凸形状の深さを深くすることが有効で あることが明確となった。ただし，凹凸形状の深さは， 痛感を低減することと滑りを抑制することに対して相 反する特性となるため, 両者の設計的な適正化が今後 の課題となる.

\section{文献}

(1) Nishiyama, S., Development and Future Subjects of Aluminum Beverage Cans (in Japanese), Packpia, Vol. 45, No. 2 (2001), pp. 10-15.

(2) Itou, T., Tsujimoto, K. and Ohkoshi, T., Development and Commercialization of Resealable Aluminum Beverage Containers, The Journal of Japan Institute of Light Metals, Vol. 52, No. 2 (2002), pp. 82-87.

(3) Ohashi, I., Tamura, S. and Matsumasa, H., Development of "DAKARA" Aluminum Bottle Can, Japan Packaging Institute Journal, Vol. 38, No. 9 (2000), pp. 868-875.

(4) Itoh, R., Aluminum Bottles Born from the Aluminum Can Technology in Responding to the 21st Century Market Needs (in Japanese), Packpia, Vol. 47, No. 6 (2003), pp. 16-19.

(5) Itoh, R., Yamazaki, K., Nishiyama, S., Han, J. and Hanabusa, Y., A Study on the Opening Characteristic of an Aluminum Bottle and Effects of the Dimensions of the Bottle, Transactions of the Japan Society of Mechanical Engineers, Series C, Vol.73, No. 729 (2007), pp. 280-287.

(6) Yamazaki, K., Chihara, T., Itoh, R. and Yamada, M., A
Study on Evaluation Method of Drinking Ease for Aluminum Bottle Cans, Proceedings of the 16th Design \& System Conference of the Japan Society of Mechanical Engineers, No. 06-33 (2006), pp. 29-32.

( 7 ) Sheik, N. I. and Chong, H. L., Modelling Wrist-twisting Strength of Elderly, Ergonomics, Vol. 31, No. 12 (1988), pp. 1807-1819.

(8) Hidaka, M., Tanaka, Y. and Watanabe, A., Time Course of Removal Torque of Cap in Child Resistant Package, Journal of the Nippon Hospital Pharmacists Association, Vol. 21, No. 2 (1995), pp. 124-130.

(9) Endo, A. and Sawashima, H., Design of Bottle Cap Based on Ergonomic Standpoint of Measurement, Japan Packaging Institute Journal, Vol.44, No. 3 (2006), pp. 212-218.

(10) Bernnum, J., Kjeldsen, M., Jensen, K. and Staehelin Jensen, T., Measurements of Human Pressure-pain Thresholds on Fingers and Toes, Pain, Vol. 38 (1989), pp. 211-217.

(11) Murakami, K. and Hasegawa, T., Novel Fingertip Equipped with Soft Skin and Hard Nail for Dexterous Multi-fingered Robotic Manipulation, Journal of the Robotics of Japan, Vol. 22, No. 5 (2004), pp. 616-624.

(12) Maeno, T., Kobayashi, K. and Yamazaki, N., Relationship between Structure of Finger Tissue and Location of Tactile Receptors, Transactions of the Japan Society of Mechanical Engineers, Series C, Vol.63, No. 607 (1997), pp. 881-888.

(13) Oshima, M., Encyclopedia of Ergonomics (in Japanese), (2005), p. 24, Maruzen.

(14) Han, J., Nishiyama, S., Itoh, R., Shinguryo, T. and Yamazaki, K., Design of New Aluminum Easy Open End with Improved Finger Access, Proceedings of the Mechanical Engineering Congress, No. 05-1 (2005-9), pp. 31-32.

(15) Yamaba, K., Kono, H. and Ozaki, S., Physical Characteristics of a Human Finger (in Japanese), Journal of the Society of Biomechanisms, No. 3 (1975), pp. 27-36. 